\title{
EMPIRICAL ANALYSIS AND INTERVENTION RESEARCH ON COLLEGE STUDENTS' HEALTH INFLUENCE MECHANISM FROM THE PERSPECTIVE OF PUBLIC SPORTS
}

OrIGINAL ARTICLE

ARTIGO ORIGINAL Artículo Original

\author{
ANÁLISIS EMPÍRICO E INVESTIGACIÓN DE INTERVENCIONES SOBRE EL MECANISMO DE IMPACTO EN LA \\ SALUD DELOS ESTUDIANTES UNIVERSITARIOS DESDE LA PERSPECTIVA DELOS DEPORTES PÚBLICOS \\ ANÁLISE EMPÍRICA E INVESTIGAÇÃO DE INTERVENÇÃO SOBRE O MECANISMO DE INFLUÊNCIA NA SAÚDE \\ DOS ESTUDANTES UNIVERSITÁRIOS SOB A PERSPECTIVA DO DESPORTO PÚBLICO
}

Mingzhu Yuan 1,2 (D)
Sports Sociology

1. Department of Public Basic Teaching, Fuzhou University of International Studies and Trade, Fuzhou, Fujian, 350202, China. 2. Department of Healthcare Administration, Asia University, Taichung, Taiwan, 41354, R.O.C.

\section{Correspondence:}

Fuzhou, Fujian, 350202, China. noon0061639@163.com

\begin{abstract}
The construction of public sports does not only improve the sports performance of college students, but also improves the health level of students. At present, the achievements of public sports construction in colleges and universities are not good, and the reasons for hindering the improvement of students' physical health are more complex. In order to explore the problems existing in the construction of public sports in colleges and universities, this study used literature survey, the Delphi method, questionnaire survey and factor analysis to analyze the health impact mechanism of college students, and carried out intervention research according to analysis results. Factor analysis was used to extract the students'factors, school factors, parents'factors and social factors from the 30 influencing factors in the questionnaire and, through empirical analysis, it summed up the students' health influence mechanism, such as learning pressure, physical education curriculum, family health attention and so on. In view of the main influencing factors, the targeted intervention, including improving the students' and parents' awareness of physical exercise and enhancing the load of physical education curriculum in colleges and universities is designed. Before and after the intervention, students'sprint and long-distance running tests show that students' physical fitness has been significantly improved, and the intervention results show that targeted intervention can promote the healthy development of college students. It is expected that this study can strengthen the level of public sports construction in colleges and universities, so as to improve students' physical quality.
\end{abstract}

Keywords: Students; health intervention; influence mechanism; factor analysis method.

\section{RESUMO}

A construção de esportes públicos não só melhora o desempenho esportivo dos estudantes universitários, como também melhora o nivel de saúde desses estudantes. Atualmente, as instalações esportivas em faculdades e universidades não são boas, e as razões para impedir a melhoria da saúde física dos estudantes são mais complexas. A fim de explorar os problemas existentes na construção de esportes públicos em faculdades e universidades, este estudo utilizou o método da literatura, o método Delphi, o método de levantamento por questionários e o método de análise de fatores para analisar o mecanismo de impacto na saúde dos estudantes universitários, e realizou pesquisas de intervenção de acordo com os resultados da análise. A análise de fatores foi usada para extrair os fatores dos alunos, fatores escolares, fatores dos pais e fatores sociais dos trinta fatores que influenciam o questionário, e através de análise empírica, resumiu-se o mecanismo de influência da saúde dos alunos, como pressão na aprendizagem, carga curricular de educação física, atenção à saúde familiar e assim por diante. Tendo em conta os principais fatores influenciadores, concebeu-se a intervenção visada, incluindo a melhoria da conscientização dos estudantes e dos pais para o exercício físico e o reforço da carga dos programas de educação física nas faculdades e universidades. Antes e depois da intervenção, o teste de sprint e de longa distância dos estudantes mostra que a aptidão física dos estudantes foi significativamente melhorada, e os resultados da intervenção mostram que a intervenção orientada pode promover o desenvolvimento saudável dos estudantes universitários. Espera-se que este estudo possa reforçar o nivel de concepção dos serviços de públicos esportivos em faculdades e universidades, de modo a melhorar a qualidade física dos estudantes.

Descritores: Estudantes; intervenção na saúde; mecanismo de influência; método de análise de fatores.

\section{RESUMEN}

La instalación de deportes públicos no solo mejora el rendimiento deportivo de los estudiantes universitarios, sino que también mejora el nivel de salud de los estudiantes. En la actualidad, los logros de la instalación de deportes públicos en colegios y universidades no son buenos y las razones que obstaculizan la mejora de la salud 
fisica de los estudiantes son más complejas. Con el fin de explorar los problemas existentes en la instalación de deportes públicos en colegios y universidades, este estudio utilizó la revisión de literatura, el método Delphi, la encuesta de cuestionario y el análisis factorial para analizar el mecanismo de impacto en la salud de los estudiantes universitarios, y llevó a cabo una investigación de intervención según los resultados de los análisis. Se utilizó el análisis factorial para extraer los factores de los estudiantes, los factores escolares, los factores de los padres y los factores sociales de los 30 factores de influencia del cuestionario y, a través del análisis empírico, se resumió el mecanismo de influencia de la salud de los estudiantes, como la presión de aprendizaje, plan de estudios de educación, atención de salud familiar, etc. Teniendo en cuenta los principales factores que influyen, se diseñó la intervención dirigida, incluida la mejora de la conciencia de los estudiantes y los padres sobre el ejercicio físico y la mejora de la carga del plan de estudios de educación física en los colegios y universidades. Antes y después de la intervención, las pruebas de carrera de velocidad y de larga distancia de los estudiantes muestran que la condición física de los estudiantes ha mejorado significativamente, y los resultados de la intervención muestran que la intervención dirigida puede promover el desarrollo saludable de los estudiantes universitarios. Se espera que este estudio pueda fortalecer el nivel de instalación de deportes públicos en colegios y universidades, de manera que mejore la calidad física de los estudiantes.

Descriptores: Estudiantes; intervenciones sanitarias; mecanismos de impacto; análisis de factores.

\section{INTRODUCTION}

Since China successfully hosted the Olympic Games, the image of China as a sports power has been established in the hearts of all countries in the world, and a strong sports upsurge has emerged in China. And this upsurge of sports has brought a guiding external environment for the construction and development of college sports in China. In recent years, more and more attention has been paid to the health problems of college students. College students are the future of the motherland, and their health is related to the progress and development of society'. With the progress of society and the development of economy, public sports plays an increasingly important role in social activities and has gradually become an important part of people's life. Under the environment of vigorously carrying out education system reform and comprehensively promoting quality education in China, the demand for talents with higher comprehensive quality is becoming stronger and stronger, and people pay more and more attention to their own health level. ${ }^{2}$ In view of this, public sports show unprecedented importance. Based on the perspective of public sports, this study analyzes and studies the health impact mechanism of college students, using the mixed method of questionnaire survey, mathematical statistics and factor analysis. Based on the above public sports perspective, the research on the mechanism of College Students' health impact is undoubtedly positive and valuable for reference in improving college students' physical health and expanding the public sports system and path, so it can be targeted analysis. ${ }^{3}$

Gustavo de Souza morettide et al. Pointed out that in the multiple regression model adjusted by age for male students, overweight was associated with marital status, family income, hypertension and daily television watching. ${ }^{4}$ Pointed out that previous studies showed that sedentary and lack of exercise were important factors leading to subhealth and physical decline of college students, which also confirmed this research. In addition to chest circumference, hip circumference and other indicators were positively correlated with the growth of sub-health.

The above research results can be found that there are a lot of researches on the influence of College Students' health mechanism, but the mixed method of questionnaire survey, mathematical statistics and factor analysis is still very few in the field of College Students' health impact mechanism research. Therefore, the research will be conducted in questionnaire survey, mathematical statistics and factor analysis Methods based on the mixed method, the influence mechanism of College
Students' physical health was studied, and the constructive suggestions were expected to be made to ensure the health of college students.

\section{EXPERIMENTAL RESULTS AND ANALYSIS}

\section{An empirical analysis on the health impact mechanism of College Students}

Four common components were extracted from 30 third-class factors by factor analysis, which could explain $81.06 \%$ of the initial influencing factors. The first public factor includes "students' exercise awareness", "exercise items", "entertainment methods", "extracurricular exercise", "sleep and diet". The second public component includes 11 factors, such as "the organization of extracurricular sports activities", "sports meeting and competition organization", "teachers' concept", "sports guidance", "health knowledge courses and lectures". The third public component includes five factors: the level of parents'sports support, genetic factors, family sports hobbies, parents'attention to sports, and parents'education methods. The fourth public component includes "convenience of sports venues", "health concern of University Administrators", "extracurricular sports guidance", "college sports funds", "national policy" and "local poli$c y$ ". By analyzing the sub factors of the above four public components, the four public components are named as students, schools, families and social factors.

The physical exercise of male and female students in student factors is shown in Table 1. About $29.20 \%$ of male students and $33.50 \%$ of female students almost do not exercise every week, while only about $10.10 \%$ of male students and $4.20 \%$ of female students do physical exercise three times or more a week. The average exercise time of male

Table 1. Physical exercise for boys and girls.

\begin{tabular}{c|c|c|c}
\hline $\begin{array}{c}\text { Weekly physical } \\
\text { activity/times }\end{array}$ & $\mathbf{0}$ & $\mathbf{1 \sim 2}$ & $\mathbf{3}$ \\
\hline Boys & $29.20 \%$ & $60.70 \%$ & $10.10 \%$ \\
\hline Girls & $33.50 \%$ & $62.30 \%$ & $4.20 \%$ \\
\hline $\begin{array}{c}\text { Weekly physical } \\
\text { exercise time/min }\end{array}$ & $0 \sim 30$ & $30 \sim 60$ & $>60$ \\
\hline Boys & $35.50 \%$ & $26.30 \%$ & $38.20 \%$ \\
\hline Girls & $46.60 \%$ & $45.80 \%$ & $7.60 \%$ \\
\hline $\begin{array}{c}\text { Motivation for } \\
\text { physical exercise }\end{array}$ & $\begin{array}{c}\text { Relieve learning } \\
\text { pressure }\end{array}$ & $\begin{array}{c}\text { Enhance } \\
\text { physical fitness }\end{array}$ & $\begin{array}{c}\text { Overcome } \\
\text { exam }\end{array}$ \\
\hline Boys & $21.00 \%$ & $25.20 \%$ & $21.80 \%$ \\
\hline Girls & $26.10 \%$ & $23.10 \%$ & $10.60 \%$ \\
\hline
\end{tabular}


students is longer than that of female students, but the exercise time of most college students is less than one hour. The main reason for boys to exercise is to improve their physique, while the main motivation of girls is to relieve the pressure of study. It can be seen from the analysis of students' physical exercise that students pay less attention to sports and health, especially girls'lack of physical exercise, which may be caused by excessive learning pressure and lack of health awareness.

Figure 1 includes the recognition degree of teachers and students and parents on the investment of college sports funds and the load of College Physical Education Curriculum under school factors, as well as the level of parents' sports participation and the types of parents' investment in education in family factors. It can be seen from Figure 4 that the satisfaction degree of school physical education investment is $70 \%$, which basically meets the requirements, but the school physical education curriculum is generally small. Most parents do not or seldom take part in physical exercise, which has a negative impact on students' awareness of physical health. $46.30 \%$ of parents'investment in children's education is intellectual investment, ignoring the cultivation of students' healthy physique. The social factors are mainly the influence of examination oriented education. The greater learning pressure makes students lack the habit of active physical exercise before university, and their health consciousness is weak. Generally speaking, the main reasons that affect the health of college students include excessive learning pressure, parents' insufficient attention to sports health, and school's design of physical education curriculum is too light.

\section{Analysis of sports health intervention}

Based on the above analysis of the influencing factors of College Students' physical health, this paper adopts the way of conducting long-distance lectures on physical health education for parents, encouraging students (especially girls) to take more extracurricular physical exercise, and strengthening the design of college physical education curriculum load to intervene college students' physical health. Taking $50 \mathrm{~m}$ running and $800 \mathrm{~m}$ running (female) / 1000m running (male) as the evaluation standard of students' physical health, the health degree of college students was tested before the intervention, at the third, sixth, ninth and twelfth months after the intervention, in order to evaluate the intervention effect.

Before and after the intervention, the average scores of sprint and long-distance running of boys and girls are shown in Table 2. In the later stage, the response speed of $50 \mathrm{~m}$ intervention for male students was slower than that of $50 \mathrm{~m}$ intervention, but the response speed of $50 \mathrm{~m}$ intervention was slower in the later stage. In the $800 \mathrm{~m} / 1000 \mathrm{~m}$ long-distance running results, the improvement of boys and girls is almost linear. At the 12th month after the intervention, the average

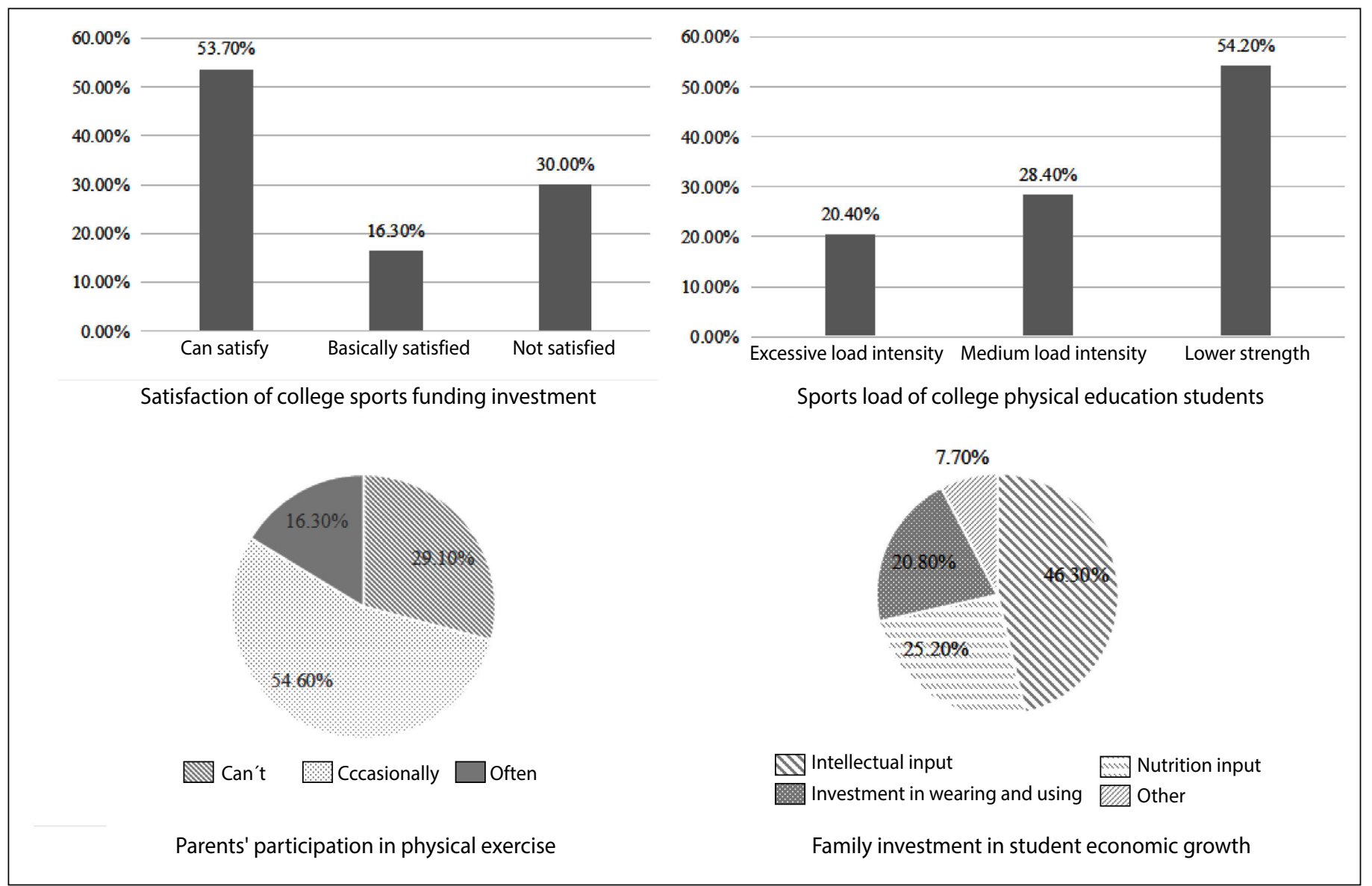

Figure 1. Some data of school factors and family factors

Table 2. The average $50 \mathrm{~m}$ and $800 \mathrm{~m} / 1000 \mathrm{~m}$ scores of boys and girls before and after the intervention.

\begin{tabular}{c|c|c|c|c|c|c}
\hline Time consuming & Gender & Before intervention & $\begin{array}{c}\text { 3 months after } \\
\text { intervention }\end{array}$ & $\begin{array}{c}\mathbf{6} \text { month after } \\
\text { intervention }\end{array}$ & $\begin{array}{c}\mathbf{9} \text { months after } \\
\text { intervention }\end{array}$ & $\begin{array}{c}\mathbf{1 2} \text { months after } \\
\text { intervention }\end{array}$ \\
\hline \multirow{2}{*}{$50 \mathrm{~m}-\mathrm{run} / \mathrm{s}$} & Boys & 8.21 & 8.02 & 7.76 & 7.5 & 7.25 \\
\cline { 2 - 7 } & Girls & 9.2 & 8.76 & 8.76 & 8.59 & 8.45 \\
\hline \multirow{2}{*}{$1000 \mathrm{~m} / 800 \mathrm{~m}-\mathrm{run} / \mathrm{s}$} & Boys $(1000 \mathrm{~m})$ & 276.21 & 267.65 & 258.87 & 249.51 & 240.45 \\
\cline { 2 - 7 } & Girls $(800 \mathrm{~m})$ & 277.45 & 268.12 & 256.21 & 246.48 & 235.15 \\
\hline
\end{tabular}


scores of male and female students in $50 \mathrm{~m}$ increased by $11.69 \%$ and $8.15 \%$ respectively, while those of $1000 \mathrm{~m} / 800 \mathrm{~m}$ increased by $12.95 \%$ and $15.25 \%$ respectively. This shows that health targeted intervention can effectively improve the physical quality of college students and improve the health level of college students.

\section{CONCLUSIONS}

In recent years, the health status of college students is generally poor, and physical exercise is the main way to keep healthy. Therefore, colleges and universities actively carry out public physical education to improve the physical quality of college students. In order to explore the targeted public physical education teaching methods, this study combined with literature survey, Delphi method, questionnaire survey method and factor analysis method to explore the health impact mechanism of college students, and based on the influence mechanism, carried out physical health intervention on college students. The questionnaire is designed by using the model modified by Delphi method, and a questionnaire survey is carried out for teachers, students and their parents in a city. Through factor analysis of the questionnaire data, four main components including student factor, school factor, parent factor and social factor are obtained. The analysis of the main components shows that learning pressure, school physical education curriculum design and parents' attention to sports health are the main factors affecting college students' health. Based on the above results, a series of physical health intervention measures were designed. Compared with before intervention, the $50 \mathrm{~m}$ running time of boys and girls decreased by $11.69 \%$ and $8.15 \%$, and the time of $1000 \mathrm{~m} / 800 \mathrm{~m}$ running decreased by $12.95 \%$ and $15.25 \%$ respectively. It can be considered that the intervention measures designed based on the mechanism of students' health impact have strong practicability. In this study, only sprint and long-distance running results are used to define the health level of students, and the evaluation of intervention results is somewhat one-sided. In the future research, we can use multi-dimensional health indicators to investigate the changes of students' health.

\section{ACKNOWLEDGEMENTS}

The study was supported by "Middle-aged and Youth (Science and Technology) Project of Fujian Provincial Department of Education 2017, China (Grant No. JAT170732); Fujian Province Education Science "13th Five-Year Plan "2018 regular topic, China (Grant No. FJJKCG-071)".

The author declare no potential conflict of interest related to this article

\section{REFERENCES}

1. Dorshkind K, Montecino-Rodriguez E, Signer RA. The ageing immune system: is it ever too old to become young again? Nat Rev Immunol. 2009; 9(1):57-62.

2. Li E. Influence of physical exercise prescription on health-related physical fitness (HRPF) of college students. Agro Food Industry Hi Tech. 2017; 28(1):2885-2887.
3. SchmittV, Rink L, UciechowskiP.The Th17/Treg balance is disturbed during aging. Exp Gerontol. 2013;48(12):1379-86.

4. Moretti GS, Muniz PT, Tavares CM. Prevalence of and factors associated with overweight among university students from 11Rio Branco, Acre - Brazil. Revista Brasilra De Cineantropometria E Desempenho Humano. 2014; 16(4):406-418 